Плотнікова Марія Федорівна кандидат економічних наук, доцент кафедри інноваційного підприємництва та інвестиційної діяльності, Поліський національний університет, бульвар Старий, 7, м. Житомир, 10008, тел.: (0412) 2214-00, e-mail: mfplotnikova@gmail.com, https://orcid.org/0000-0003-2852-3009

Присяжнюк Оксана Федорівна кандидат економічних наук, доцент кафедри менеджменту організацій та адміністрування імені Миколи Поліщука, Поліський національний університет, м. Житомир, 10008, бульвар Старий, 7, тел.: (0412) 2214-00, e-mail: oksana_himich@ukr.net, https://orcid.org/0000-0003-0066-9065

\title{
РОЛЬ ФРІЛАНСИНГУ У РЕАЛІЗАЦІЇ ПРОСКТІВ ТА ФОРМУВАННІ КВАЛІФІКАЦІЙНИХ ЗДІБНОСТЕЙ ФАХІВЦІВ
}

Анотація. Цифровізація економіки, як один зі стратегічних напрямів розвитку України, посилює увагу на розвитку дистанційних форм підприємництва. Однією із таких може бути фріланс. Лідируючими проявами цієї діяльності в Україні $є$ переклади і копірайтинг. Значні позиції займають маркетинг, реклама, консалтинг, дизайн та розробка веб-сайтів. Основними перевагами фрілансингу визначено можливість вільного вибору проєкту, часу його виконання та оплати за свою працю, суміщення цієї праці з основною діяльністю. Перешкодами у розвитку фрілансингу є недоліки у законодавчому забезпеченні цієї діяльності, нестабільність заробітку, особисте виснаження, відсутність соціального забезпечення та наявність випадків недобросовісності серед виконавців і замовників. Отже, наявна достатня кількість ризиків та відсутність гарантій якості виконання роботи. Частково ці перешкоди ліквідуються за допомогою функціонування спеціальних сайтів, де фіксується інформація про рівень виконання фрілансерами поставлених завдань.

Пандемія посилила увагу керівників бізнес-організацій до дистанційної форми виконання завдань співробітниками. Нещодавно внесені поправки до Трудового кодексу. Вони стосуються особливостей договірної діяльності, режиму робочого дня, належних умов праці та відпочинку працівників, що працюють дистанційно. Значної уваги при цьому заслуговує дистанційний менеджмент та залучення працівників на договірній основі. Фріланс допомагає зробити проєкти менш витратними Діяльність фрілансерів зосереджує увагу на забезпеченні саморозвитку та самоорганізації. Найкращою рекламою діяльності фрілансерів $є$ максимум позитивних відгуків про результати їх виконаної роботи. Надання правдивої інформації про себе також $є$ передумовою успіху. Важливо у цій діяльності бути ввічливим при спілкуванні з потенційними клієнтами. Основою для розвитку фрілансингу $\epsilon$ розвиток технологій та технічне забезпечення. Зрозумілий механізм роботи створюють інтернет-біржі 
фрілансерів. Важливими є зустрічі, обмін інформацією між фрілансерами. Це дозволить виявити спільні проблеми та недобросовісних замовників.

Ключові слова: фріланс, самоменеджмент, проєкт, розвиток професійних здібностей, дистанційний менеджмент.

Plotnikova Maria Fedorivna Candidate of Economic Sciences, Associate Professor of the Department of Innovative Entrepreneurship and Investment Activity, Polissia National University, Zhytomyr, 10008, Staryi Boul., 7, tel.: (0412) 22-14-00, e-mail: mfplotnikova@gmail.com, https://orcid.org/0000-0003-2852-3009

Prysiazhniuk Oksana Fedorivna Candidate of Economic Sciences, Associate Professor of the Department of Management of Organizations and Administration named after Mykola Polishchuk, Polissia National University, Staryi Boul., 7, Zhytomyr, 10008, tel.: (0412) 22-14-00, e-mail: oksana_himich@ukr.net, https://orcid.org/0000-0001-8661-2101

\section{THE ROLE OF FREELANCE IN THE IMPLEMENTATION OF PROJECTS AND FORMATION OF QUALIFICATION ABILITIES OF PROFESSIONALS}

Abstract. Digitalization of the economy, as one of the strategic directions of Ukraine's development, increases the attention to the development of remote forms of entrepreneurship. One of these can be freelance. The leading manifestations of this activity in Ukraine are translations and copywriting. Significant positions are occupied by marketing, advertising, consulting, website design and development. The main advantages of freelancing are the ability to freely choose the project, the time of its implementation and payment for their work, combining this work with the main activity. Obstacles to the development of freelancing are shortcomings in the legislative provision of this activity, instability of earnings, personal exhaustion, lack of social security and the presence of cases of dishonesty among contractors and customers. Therefore, there are sufficient risks and no guarantees of quality of work. In part, these obstacles are eliminated through the operation of special sites, which record information about the level of performance of freelance tasks.

The pandemic has increased the attention of business leaders to the remote form of employee performance. The Labor Code has recently been amended. They relate to the specifics of contractual activities, working hours, proper working conditions and recreation of employees working remotely. Remote management and involvement of employees on a contractual basis deserves considerable attention. Freelance helps to make projects less expensive Freelancers focus on self-development and selforganization. The best advertising of freelancers is a maximum of positive feedback on the results of their work. Providing truthful information about yourself is also a prerequisite for success. It is important in this activity to be polite when communicating with potential customers. The basis for the development of freelancing is the development of technology and technical support. An understandable mechanism of work is created by online exchanges of freelancers. Meetings and exchange of 
information between freelancers are important. This will identify common problems and unscrupulous customers.

Keywords: freelance, self-management, project, development of professional abilities, remote management.

Постановка проблеми. Цифровізація, за багатофакторності свого генезису, стосовно вітчизняної економіки і соціальних інститутів носить індукований характер. Технологічна гонка, що асоціюється $з$ так званим штучним інтелектом, а по суті 3 вирішенням інтелектуальних завдань, заснованих на концепціях машинного навчання i великих даних, таких як розпізнавання образів, розпізнавання і генерація мови тощо, є значимий фактор конкуренції між країнами. В рамках цієї конкуренції Україна, як джерело суверенітету, змушена проводити цифровізацію темпами, що продукують високі, багато в чому неминучі ризики. Крім усього іншого технологічні процеси, як i раніше, накладаються на існуючі національні проблеми, які об'єктивно не залежать від розвитку цифрових технологій: складна логістика; помітна нерівномірність економічного розвитку регіонів, розподілу та доступності ключових ресурсів (у тому числі населення) на території країни. Високі темпи технологічного розвитку, за фактом безпосередньо «зануреного» у базові економічні, соціальні та інфраструктурні процеси, є однією 3 ключових причин інституційних змін у суспільстві.

Аналіз останніх досліджень і публікацій. Питанням самоменеджменту та фрілансингу приділяли увагу багато вчених, зокрема 3 позиції формування трудових відносин, адміністрування суспільно-економічними процесами та становлення сучасної особистості-фахівця. Такими $є$ дослідження М. Алексинської, Г. Архангельського, В. Білошкапа, А. Бішофа, А. Вдовиченка, О. Грішнової, Л. Зайверта, С. Кові, Д. Костюка, А. Малишева, Й. Ніссена, Н. Реверенда, О. Савченка, Н. Самолюка, Т. Скиби, Н. Солярчука, Д. Стребкова, О. Тертичного, Д. Фернера, А. Шевчука, Р. Шуляра та інших. Автори приділяють увагу як специфіці становлення фахівця, формування відповідних кваліфікації та навичок, а також подальшим аспектам роботи на засадах самоменеджемнту.

Мета статті - виявлення та формування професійних компетентностей фахівців у системі адміністрування процесів самоменеджменту як одна 3 цілей сталого та науково-технологічного розвитку на їх конкурентоспроможності.

Виклад основного матеріалу. Цифровізація трансформує характер i структуру економіки країн і цілих регіонів. Внутрішньогалузева конкуренція зростає, ринки розширюються, конкурентоспроможність галузей окремих країн на світових ринках підвищується. Цифрові перетворення - одна з головних детермінант світового економічного зростання. За оцінками фахівців, потенційний економічний ефект від цифровізації економіки України збільшить ВВП країни до 2025 р. на 12 трлн грн, що складе від 19 до 35\% прогнозованого зростання ВВП. У межах цифрової трансформації виробництв люди, машини, продукти і системи за допомогою інформаційно-комунікаційних технологій та 
Інтернету об'єднуються у динамічну саморегулюючу мережу (структуру) реального часу, де відбувається зміна концепцій створення цінностей [1]. Індустрія 4.0 характеризує поточний тренд розвитку автоматизації та обміну даними, являє собою новий рівень організації виробництва та управління ланцюжком створення вартості протягом усього життєвого циклу продукції, що випускається. Четверта промислова революція заснована на застосуванні глобальних промислових мереж, які включають досягнення НТР, нейромережі, біотехнології, штучний інтелект (рис. 1).

Фріланс є новим словом у системі зайнятості. Наразі це IT-фахівці, принтдизайнери, програмісти, SEO-фахівці, журналісти, дизайнери, менеджери, копірайтери, перекладачі, фахівці з просування сайтів тощо, - як правило ту, хто повністю чи частково може працювати у віртуальному середовищі чи з визнаною періодичністю. Ком'юніті і спільноти фрілансерів, а також інших віддалених співробітників є можливістю самореалізації і отримати додатковий заробіток. За даними опитування сайту FreelanceJob від 100 до 150 \$ заробляють $15 \%$ опитаних фрілансерів, від 150 до $300 \$-23 \%$, від 300 до $600 \$-23 \%$. Від 600 до $1000 \$$ отримують $18 \%$, понад $1000 \$$ - кожен п'ятий (20\%).

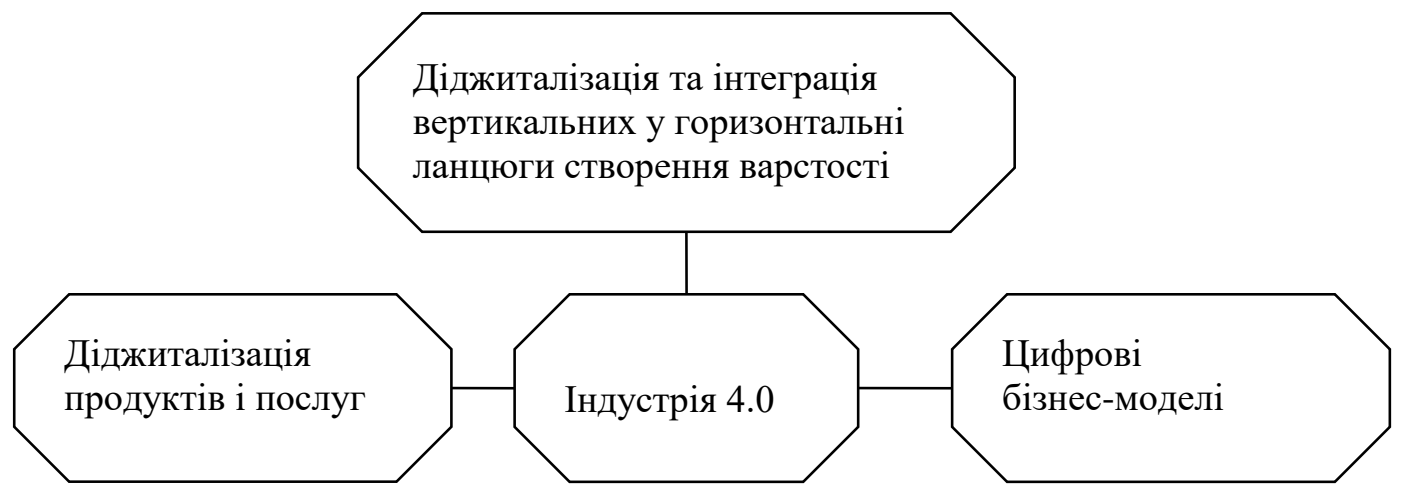

Рис. 1. Складові концепиії Індустрія 4.0

При цьому важливо враховувати, що для багатьох фріланс - це додатковий заробіток. Мабуть 3 цих причин велика частина українських фрілансерів продовжує суміщати основну діяльність на постійній роботі 3 віддаленою незалежною роботою (рис. 2). 


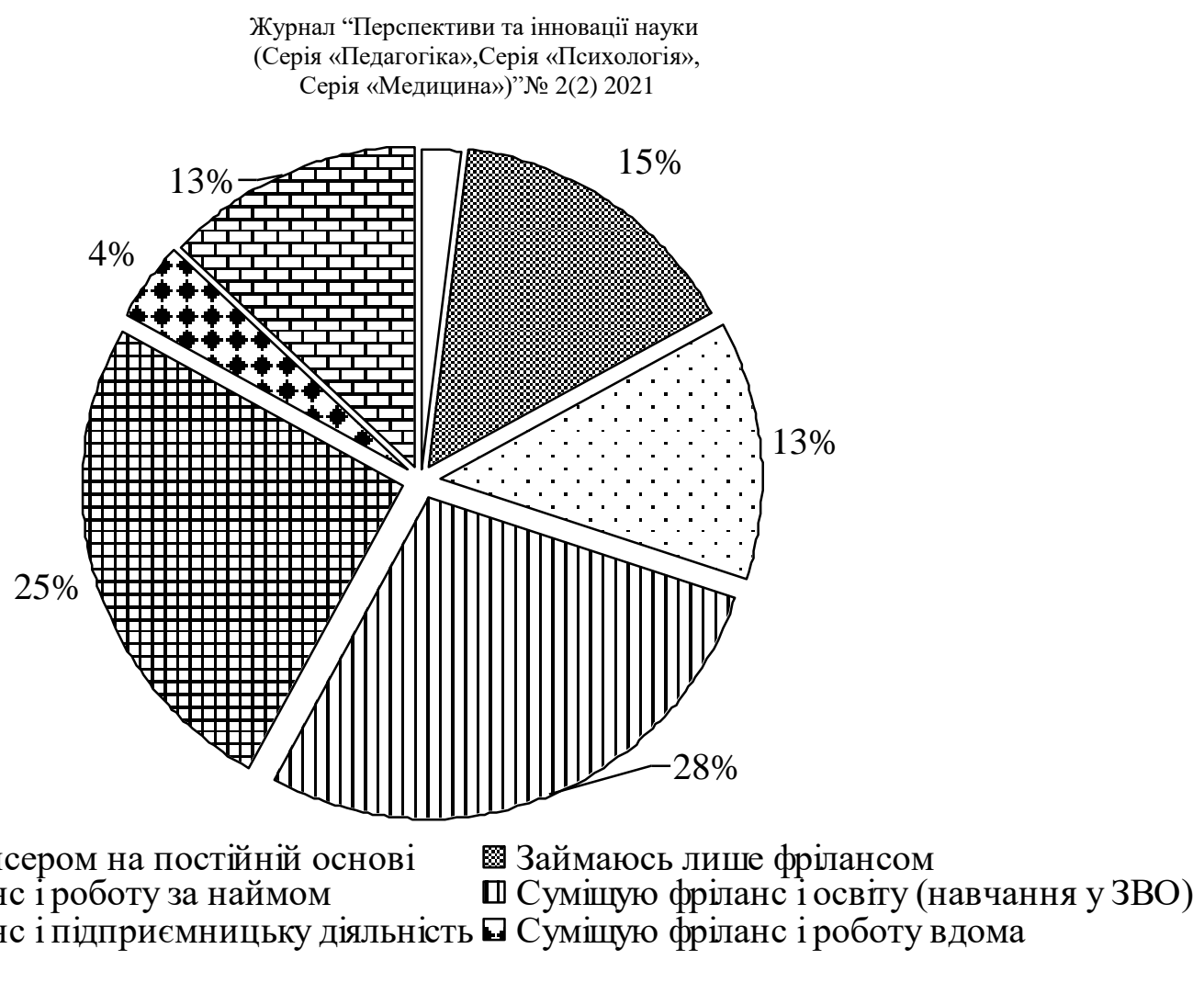

$\square$ Працюю фрілансером на постійній основі

$\checkmark$ Сумішую фріланс і роботу за наймом

Займаюсь лише фрілансом

四 Сумішую фріланс і підприємницьку діяльність С Сумішую фріланс і роботу вдома

由 Інші види робіт

\section{Pис. 2. Суміщення фрілансу з іншою діяльністю}

Локдаун, як криза для багатьох, дав поштовх розвитку, зокрема фрілансерства. Представники творчих професій, які втратили роботу, стали керівниками самі собі. Консультанти, піарники, айтішники з різних сфер приєдналися до гурту «вільних художників», що здебільшого складалася 3 перекладачів, дизайнерів і фотографів. Фріланс може стати першим кроком до створення малого бізнесу, тому для розвитку економіки такий тренд цілком позитивний. Багато з тих, хто в умовах кризи пішов у вільне плавання, ще зовсім нещодавно і не думали про таку можливість і поступово будували корпоративну кар'єру. Наразі фрілансом займаються офісні працівники, які втратили роботу, мами, які знаходяться у відпустці по догляду за дитиною та інші [2]. Наявність невеликої кількості вільного часу і порада друга чи подруги-фрілансера - саме ці дві обставини часто стають передумовою «звернення» до «вільних Списоносців» (freelancer з англ.). Фріланс як явище і, наприклад, копірайтинг, як вид діяльності можуть стати відкриттям для самої людини. Можливість самостійно планувати свій робочий час, самостійно обирати проекти і встановлювати розмір оплати праці - ось те, що на думку фрілансерів додає популярності цьому способу занятості [3].

Плюси фрілансу очевидні: 1) незалежність та самовираження (працюєш на себе, сам вибираєш проєкти, які тобі цікаві, людей, 3 якими готовий співпрацювати, можеш працювати цілодобово безперервно або формувати власний графік роботи [6-7]); 2) «вільний графік з можливістю регулювати свою завантаженість (скажімо, відхиляти нові або невідповідні замовлення), а вибір щодо понаднормових або вихідних вирішується за рахунок перемоги ліні над жадібністю, можливість працювати вдома; 3) ніким не регульоване ціноутворення - кожен сам собі господар (однак, тут, як і скрізь, є крайнощі: знає 
собі ціну еліта, найчастіше прийшла з офлайнових студій і журналів, і демпери, новачки і школярі, хапають все, що погано лежить); 4) необхідність постійної самоосвіти (ринок скрізь ринок), потреба постійно розвиватися, обираючи різні проєкти, знайомлячись 3 новими людьми i компаніями (коло спілкування постійно зростає); 5) «можливість вибору» робочого завдання (погоджуватися на найбільш цікаві в даний момент проєкти, самостійно планувати свій час, адже підзвітність лише наймачеві за результат роботи, i він практично ніколи не втручається в проєкт); 6) відповідальність лише за себе (не можуть підвести «суміжники», не потрібно підлаштовуватися під бажання, уміння і навички колег); 7) відсутність додаткових витрат на транспорт, обіди (скорочення витрат по податках i виплатах, відсутність витрат на утримання робочого місця енергоресурси, канцтовари, амортизація, побут, а також відсутність штатної одиниці на разові завдання, наприклад: випуск pos-матеріалів, настройка сервера, створення сайту); 8) можливість самореалізуватися в різних областях знань, що практично неможливо при роботі в офісі на певній посаді (віддалена робота дозволяє вийти за рамки звичних обов'язків); 9) якщо кандидат приходить у фірму, то у нього попросять диплом, запитають про стаж роботи, який потрібно підтвердити документально, а замовники фрілансерів більше дивляться на фактичні роботи кандидата, на його реальне резюме; 10) маючи постійний дохід, можна що-небудь заробити, а якщо мати постійних замовників, то і істотно збільшити постійний щомісячний дохід». До мінусів можна віднести 1) високу професійну (i не дуже) конкуренцію, сумлінних замовників чи сумнівних виконавців, робота 24 години на добу; 2) існує ризик бути обдуреним (відсутність гарантій оплати для виконавця, як і гарантій виконання роботи для замовника); 3) нестабільність заробітку, доводиться додатково мотивувати себе до роботи (не кожній людині властива самоорганізованість і дисциплінованість); 4) проекти «приходять» нерівномірно (іноді відразу кілька, а іноді буває деяке затишшя); 5) відсутність «соціального пакету» (гарантованих постійною роботою «принад»у вигляді медичної страховки, оплати лікарняного листа, відпустки, пенсійні відрахування додаткових виплат, оплачуваних вихідних та відпустки; 6) відсутність гарантій виконання роботи, а також самого працівника в офісі («під рукою») для вирішення невідкладних завдань, хоча друге цілком успішно вирішується сучасними системами спілкування і передачі інформації; 7) відсутність стабільного колективу і т. д. і т. п. - навіть приходячи у компанію, фрілансер лише тимчасовий співробітник, контакти і зв'язки якого апріорі $\epsilon$ тимчасовими) [4]. У той же час фрілансинг змушує сподіватися тільки на себе, так як зарплата залежить від того, скільки сил і часу в це вкладається. Пандемія засвідчила потребу налагодити віддалену форму роботи понад 30\% співробітників. Компанії зі співробітниками, які працюють віддалено мають можливість економити на витратах для будь-якого офісу. Також можна обирати нового фахівця під конкретні проєкти. Тому кадрові процедури часто віддають на аутсорсинг, який є ефективним у разі наявності грамотного адміністратора.

Для одних фріланс - радість і задоволення, для інших - мука і біль головне, щоб залишалася людяність у відносинах і існувало розуміння між замовником $\mathrm{i}$ 
виконавцем, впевнена. Від замовника важливо доступне і повне пояснення того, чого він від вас чекає. Коли замовник і виконавець на одній хвилі, то все виходить. Для клієнта перший камінь спотикання у співпраці з фрілансером - це все ті ж ризики і гарантії. Довіра до компанії у багатьох випадках вища, ніж до фрілансера, проте, напрацьовані «всередині» контакти допомагають вирішити цю проблему. Клієнти звикають працювати не тільки з компанією, але і зі своїм менеджером або консультантом, знають, як працює людина, і готові йому довіряти. До того ж старі клієнти - це джерело нових контактів, і деяким підприємливим фрілансерам вдається швидко зловити хвилю в новому незалежному житті, не обмеженою корпоративними правилами i політиками, i вийти на набагато більші доходи. Оскільки Інтернет залишається якоюсь знеособленою середовищем, то пошук конкретної людини в ньому залишається складним завданням. На сайтах free-lance $\epsilon$ спільноти «чорний список», де користувачі розповідають свої історії і залишають дані неплатників, де всі ці контакти зібрані в одну базу. Фрілансери намагаються спілкуватися один 3 одним, зустрічаються поза мережею, - а це допомагає у визначенні недобросовісних замовників. Крім того, спеціалізовані сайти надають інформацію про небажаних роботодавців, наприклад, через форуми або систему відгуків, але ніхто не заважає зареєструватися людині під новим користувачем $\mathrm{i}$ почати діяльність з чистого аркуша. У цьому сенсі потрібно дивитися на непрямі ознаки того, що замовник не буде платити за виконану роботу. Прикладом таких ознак може бути категорична відмова скористатися системою безпечних угод або внести передоплату. Також фрілансеру варто задуматися, коли роботодавець пропонує занадто завищену оплату за виконання замовлення. $€$ клієнти, які оплачували замовлення через кілька місяців після повного виконання роботи. Це має місце, але постійним клієнтам, в основному, прощається. Однаковою мірою зустрічаються на практиці «Офіційний» і «неофіційний Фріланс».

Для якісної та ефективної роботи поза компанією необхідно: 1) створити собі ім'я хорошого професіонала у тій сфері, якою планує займатися фахівець, а також мати зв'язки (без цього практично неможливо створити імідж на ринку i почати працювати самостійно. - якщо про вас не знають - вас не будуть залучати до подібної діяльності, тому якісний досвід і грамотно складене резюме - перший крок до успіху); 2) ніколи не зупинятися (саморозвиток, участь в різних конкурсах, конференціях i форумах - все працює на вас); 3) не боятися самостійності і вірити в себе; 4) робити свою роботу завжди якісно і в строк. Саме це є передумовою набуття необхідної ваги в суспільстві фрілансу і дасть змогу залучення нових замовників; 5) вчитися цінувати свою працю відразу (не працювати за копійки); 6) розміщувати актуальну і правдиву інформацію про себе і свої роботи (розміщувати роботи, які можна було б продемонструвати посилання на сайт тощо); 7) якщо братися за проект, то доводити його до кінця (після успішного виконання проекту просити замовника / роботодавця написати відгук або рекомендаційний лист); 8) головне - терпіння і праця (не завжди успіх приходить відразу - не варто відразу ж гнатися за високооплачуваними замовленнями, починати поступово, заробляти репутацію, позитивні відгуки від 
замовників, i, що важливо, не опускати руки і вірити, що все вийде); 9) хороші замовники цінують не дешевизну, а якість - ніколи не сумувати; 10) починаючи 3 невеликих проектів, набиратися досвіду і знань; 11) фрілансери повинні чітко знати, що в будь-якому випадку потрібно працювати (багато початківців гублять себе тим, що не хочуть братися за невеликі замовлення, які теж несуть прибуток, міркуючи, що краще виконати 3 великих замовлення, ніж розмінюватися на 10 невеликих, - але для початківця фрілансера це як мінімум неефективно - краще спочатку попрацювати на реноме, виконати кілька невеликих проектів, заповнити профайл, той досвід, який буде отриманий на маленьких роботах, буде безцінний при роботі над великими проєктами).

Існуючий наразі дефіцит кваліфікованих кадрів (він варіюється від 40 до $50 \%$ ) на фоні скорочення працездатного населення на 12\% до 2030 р. [5] може бути вирішене за рахунок інформаційних систем i науково-технологічного розвитку країни. Функціонування існуючих інтернет-бірж фрілансерів забезпечується за рахунок зрозумілого механізму роботи. Водночас, відчувається відсутність правової бази, що дозволяє захистити як роботодавців, так i фрілансерів. У країнах Західної Свропи і США вже діє законодавство, що підкріплює роботу фрілансерів. Даний вид дистанційної роботи вже зміцнився в умах європейців та не має чіткого визначення у правовому полі України. Власники бізнесу будують свої організаційні схеми, використовуючи класичний менеджмент. I лише одиниці допускають впровадження елементів дистанційного найму співробітників, використовуючи гнучкий графік роботи i договірну основу. Як видно на рис. 3 в Україні лідирують фрілансери, що займаються текстами, перекладами і копірайтингом - 43\%. Однак, ця тенденція 3 роками може істотно змінитися в силу подальшої спеціалізації.

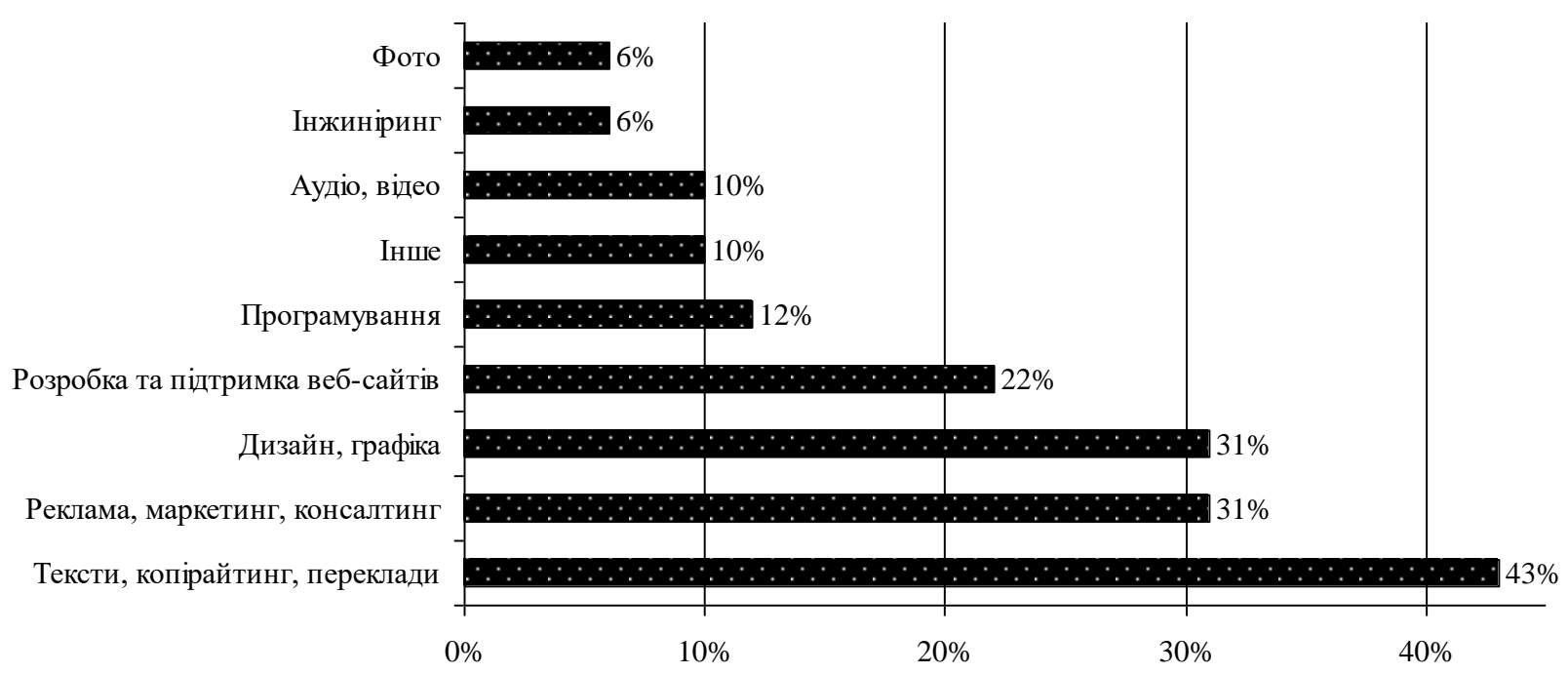

Рис. 3. Спеціалізація фрілансерів

На нашу думку, система трудових взаємовідносин між замовниками та фрілансерами має регулюватися державою через певний порядок процедур, що дозволяє законодавчо закріпити відповідальність усіх сторін, визначити порядок 
оподаткування та соціальних гарантій суб'єктів бізнесу. Надалі вільно у рамках законодавства зможуть здійснювати свою діяльність біржі праці та легально працювати фрілансери. Це зміцнить довіру до дистанційного виду діяльності, дозволить більш ретельно вивчити всі аспекти спеціалізації. Відносно недавно внесених поправок до Трудового кодексу особливості регулювання праці дистанційних працівників передбачають визначення категорії «дистанційна зайнятість» як виконання визначеної трудовим договором трудової функції поза місцем знаходження роботодавця, його філії, представника, іншого відокремленого структурного підрозділу (включаючи розташовані в іншій місцевості), поза стаціонарним робочим місцем, територією або об'єктом, що прямо або побічно перебувають під контролем роботодавця, за умови використання для виконання даної трудової функції та для здійснення взаємодії між роботодавцем i працівником 3 питань, пов'язаних 3 ii виконанням, інформаційно-телекомунікаційних мереж загального користування, у тому числі мережі Інтернет. Також прописані особливості укладення трудового договору, організації та охорони праці, режиму робочого часу i часу відпочинку дистанційних працівників.

Наразі на популярних інтернет-майданчиках фрілансерів світу у середньому зареєстровано понад 1 млн. виконавців. Замовнику достатньо опублікувати проєкт, конкурс або завдання і зацікавлені фрілансери почнуть пропонувати свої послуги. Далі визначається бюджет і терміни виконання роботи. Залишиться тільки вибрати відповідного виконавця і зарезервувати певну суму грошей в якості гарантії оплати. Для фрілансерів щодня публікується понад 1500 проєктів. У першу чергу виконавцю необхідно заповнити своє портфоліо, вказати в ньому навички роботи, розмістити приклади успішно виконаних проєктів і замовлень. Повнота і якість розміщеної інформації підвищить шанси фрілансера отримати завдання, відповідне його спеціалізації.

У Київській області щорічно збільшується кількість компаній i індивідуальних підприємців, які використовують послуги фрілансерів. Вже зараз на біржі фрілансу зареєстровано понад 800 співробітників з цього регіону. Вони пропонують послуги віддаленої роботи за різними напрямками. Найбільш популярними послугами є: розробка сайтів, написання різних текстів, розробка дизайну архітектури, програмування, консалтинг, підготовка перекладів, розробка комп'ютерних ігор, аудіо та відео, графіка, інжиніринг, робота 3 фотографіями, просування і реклама, дистанційне навчання, оптимізація сайтів (CEO). Успішно функціонують такі замовники послуг фрілансерів як рекламні агентства, розважальні центри, мережі готелів і кафе, туристичні агентства, будівельні та оздоблювальні компанії, лінгвістичні центри, поліграфічні підприємства та інші, а також поодинокі замовлення. Важливо відзначити високий рейтинг фахівців фрілансу Київської області. Понад 30\% регіональних фрілансерів мають у портфоліо 100\% позитивних відгуків за результатами роботи. В основному це досвідчені фахівці з профільних напрямів, які регулярно $і$ якісно виконують проєкти. Необхідно відзначити, що близько $20 \%$ зареєстрованих користувачів виконують разову роботу, а 50\% - новачки у цій 
справі, які мають слабке портфоліо.

Незважаючи на те, що фріланс дає відчуття свободи i незалежності, їм доводиться щодня контролювати і організовувати свій робочий день. А також створити свою власну структуру і систему самоідентифікації у світі бізнесу. Фрілансери несуть повну відповідальність за результати своєї діяльності. У них немає наставників i керівників, які контролюють роботу i прикривають їх недоліки в процесі виконання завдання. Через це часто виникає відчуття вразливості і незахищеності. До того ж фрілансери відносяться до такого типу людей, які здатні надмірно працювати. Такий трудоголізм і відсутність поділу відпочинку і праці можуть привести до вигорання особистості. Серйозною проблемою $є$ психологічна залежність від роботи за комп'ютером. Можна провести паралель із залежністю від соціальних мереж, настільки популярною зараз. Так як робота фрілансерів повністю залежна від замовлень через інтернет вони знаходяться в постійній напрузі в очікуванні хорошої пропозиції. Їм також необхідно оперативно реагувати на пропозиції, щоб їх замовлення не пішов до іншого виконавця. Таким чином, доведеться із завидною регулярністю перевіряти електронну пошту i базу бірж в пошуках потрібних пропозицій. Відповідно відбувається дисбаланс між робочим і особистим життям, між реальністю i віртуальним світом. Виходом 3 цієї ситуації може стати укладення довготривалого договору на співпрацю 3 організацією, яка приймає умови дистанційної роботи співробітників. Такий підхід дозволить поліпшити атмосферу діяльності фрілансерів, систематизувати їх робочий час i графік виконання зобов'язань. Важливим аспектом $є$ не пошук одиноких фрілансерів, а формування структури дистанційного менеджменту. У такому випадку дистанційний менеджмент - це сукупність методів і засобів управління виробничим процесом в організації по-засобом залучення територіально віддалених незалежних співробітників на договірній основі. Необхідно створити ефективні комунікації між усіма віддаленими співробітниками для виконання спільних завдань. Саме така система дозволить вирішити більшість проблем, що виникають в процесі фрілансу. Як показало проведене Інтернет-опитування, серед 1800 респондентів найбільш характерними для наших громадян $\epsilon$ фіксований i вільний графіки роботи - їх вказали 40\% і 39\%, відповідно. Основними плюсами фіксованого графіка роботи назвали стабільність i можливість заздалегідь планувати свій вільний час. Для тих, кому ближче вільний графік, головне - можливість самостійно вибирати час для виконання роботи i не «просиджувати штани в офісі», коли все вже зроблено. Гнучкий графік знаходять для себе зручним $10 \%$ учасників опитування. Найменш популярним виявився позмінний графік роботи $(8 \%)$.

Головним ідентифікатором фрілансера $є$ його профайл на сайті. Також це може бути анкета на спеціалізованому сайті, або, наприклад, сторінка в соціальній мережі чи власний блог. Оскільки профайл на сайті $\epsilon$ електронна уніфікована форма резюме на папері, то і принципи його написання такі ж, як при складанні резюме. Хоча є і деякі відмінності. Як помічають самі фрілансери, під час спілкування 3 клієнтами і потенційними замовниками не завадить почуття 
такту, ввічливість і терпіння.

Висновки. Аналізуючи практику найрозвиненіших платформ розумних центрів світу, можна виділити технології, які становлять їх основу: мобільний зв'язок 4G, 5G; смартфони і публічні Wi-Fi; енергоефективність і економія ресурсів, «розумні» лічильники; використання відновлюваних джерел енергії; екологічний транспорт; поза використанням інтелектуальних мережевих технологій; електронна демократія; утилізація сміття, а також охоплює все ширший перелік суспільних сфер, активно реалізуються через систему аутсерсингу та фрілансингу. Найістотніше, що в Україні сформувалося стійке уявлення про стандарт зайнятості і повний робочий день. Багато у чому це пов'язано з уявною стабільністю зайнятості, соціальними гарантіями, стабільним доходом і, звичайно, отриманням пенсії.

У фрілансі все залежить від самої людини. Необхідно мати в портфоліо ряд успішно завершених робіт і позитивні відгуки від роботодавців. Інтернет ресурси дозволяють фрілансерам (виконавцям) за допомогою платних сервісів активно рекламуватися себе на сайті, тим самим залучаючи замовників або роботодавців.

\section{Jimepamypa:}

1. Sadowski J. When data is capital: Datafication, accumulation, and extraction. Big Data \& Society. 2019. Vol. 6, Is. 1. P. 1-12. https://doi.org/10.1177/20539517 18820549

2. Sambamurthy V., Grover V. Shaping Agility through Digital Options: Reconceptualizing the Role of Information Technology in Contemporary Firms. MIS Quarterly. 2003. Vol. 27. P. 237-263.

3. Gong Z., Zhong A.-G., Zhu Z.-M. Conceptual Model and Strategy Analysis of Intercultural Management in International Enterprises. Science and Technology Management Research. 2016. Vol. 3. P. 58-60.

4. Matt C., Hess T., Benlian A. Digital Transformation Strategies. BISE. 2015. Vol. 57, No. 5. P. 339-343.

5. Ensuring National Economic Security Through Institutional Regulation of the Shadow Economy / V. Plotnikov, M. Golovko, G. Fedotova, M. Rukinov. Digital Economy: Complexity and Variety vs. Rationality: [proceedings of the 9th National Scientific and Practical Conference (Vladimir, Russia, April 17-18, 2019) / ed. by Elena G. Popkova, Bruno S. Sergi. Cham (Switzerland): Springer Nature Switzerland $A G, 2020$. P. 342-351. https://doi.org/10.1007/978-3-030-29586-8.

6. Ходаківський Є.І., Іванюк О.В., Плотнікова М.Ф. Парадигма гештальтів управлінських систем. Інтелект XXI. 2018. № 1. С. 206-210.

7. Ходаківський Є.І., Якобчук В.П., Захаріна О.В., Плотнікова М.Ф., Іванюк О.В. Формування європейської системи Q-менеджменту в децентралізованих громадах. Науковi горизонти. 2019. № 3. С. 10-18.

\section{References:}

1. Sadowski J. (2019). When data is capital: Datafication, accumulation, and extraction. Big Data \& Society, 6 (1), 1-12. Retrieved from https://doi.org/10.1177/20539517 18820549

2. Sambamurthy V. \& Grover V. (2003). Shaping Agility through Digital Options: Reconceptualizing the Role of Information Technology in Contemporary Firms. MIS Quarterly, 27, 237-263.

3. Gong Z., Zhong A.-G. \& Zhu Z.-M. (2016). Conceptual Model and Strategy Analysis of Intercultural Management in International Enterprises. Science and Technology Management Research, 3, 58-60.

4. Matt C., Hess T. \& Benlian A. (2015). Digital Transformation Strategies. BISE, 57(5), 339-343. 
5. Plotnikov, V., Golovko, M., Fedotova, G. \& Rukinov, M. (2020). Ensuring National Economic Security Through Institutional Regulation of the Shadow Economy / Digital Economy: Complexity and Variety vs. Rationality. Proceedings of the 9th National Scientific and Practical Conference (Vladimir, Russia, April 17-18, 2019) / ed. by Elena G. Popkova, Bruno S. Sergi. Cham (Switzerland): Springer Nature Switzerland AG, 342-351. Retrieved from https://doi.org/10.1007/978-3-030-29586-8.

6. Khodakivsky, Ye, Ivanyuk, O. \& Plotnikova, M. (2018). Paradyhma heshtal'tiv upravlins'kykh system [Gestalt paradigm of control systems]. Intelekt XXI - Intelligence XXI, 1, 206210 [in Ukrainian].

7. Khodakivsky, Ye., Yakobchuk, V., Zakharina O., Plotnikova, M. \& Ivanyuk O. (2019). Formuvannia ievropejs'koi systemy Q-menedzhmentu v detsentralizovanykh hromadakh [Formation of the European system of Q-management in decentralized communities]. Naukovi horyzonty Scientific Horizons, 3, 10-18 [in Ukrainian]. 